\title{
日本産中新世のタカアシガニについて
}

\author{
插図 1 \\ 今泉力蔵 \\ (東北大学教養学部地学教室)

\section{Miocene Macrocheira from Japan} \\ With Plate 1 \\ Rikizo IмAIzum \\ (Tohoku University)
}

山形県尾花沢市薬師沢支流の銀山層上, 烟砂岩部層より産した指先化石の上面の広い 溝, 保存されている 8 ケの歯, 第 9 歯の破揖跡扎よび内側の溝等を, 伊勢湾産のタカアシ ガニ・雌の左鈷脚不動指と比較するに, よく一致し, また全体として, 圧縮された太い形 態を有し, Macrochcira ginzanensis n. sp. とされる。

圧縮された太い形態は, 雌雄変異によるか, 種の差異によるか, いずれかであるらが, Fauna japonica 等によるも, Macrocheira kaempferi の雄の鉗脚は雌のより長いが, 指部には, このような変異が見られない。中新世の Macrocheira は, 現生種に比較して 小さく且つ太い形態をもっていたものと考光られる。 Macrocheira の巨大化は, 中新世 以後に括こり，その分布が限られたものであろう。

長野県下伊那郡千代村米川の千代小学校々庭の富草層群米川層中部より, カ二の前節抒 よび指節を有する大きな歩脚破片を産している。その表面の疮状円形突起は, 中央に円い 凹みを有し, タカアシガニの疮状円形突起に近似する。また, この歩脚破片の保存されて いる灰色シルト岩片上に, 肝域の破片がある。これは, 印象なので左肝域であるが, 疗状 突起の配列は, 現生タカアシガニと比較するに, よく一致して拈り, 微細な構造もよく保 存されている。その大きさより, 肝域は歩脚破片と別の個体に属するものである。Macrocheira sp. として, 記載しておく。

これらの産した千代小学校々庭北側の崖の同層準よりは, 前に筆者の報告した Paratymolus yabei ImAizumi, 1957 が産している。小さい標本で, Paratymolus pubescens に 似ており，その眼柄の大きい点は，Paratymolus の祖先型と考㝋られたが，甲面各域は 不明瞭ながら区分されており, 甲面に疣状突起を散在し, 鰓域には, 擢皱が発達し, 体の 小さいことと，眼柄の大きいことは，Macrocheira の子供なることを示している。

その産状が20個体も密集して扣り，ともに，Macrocheira sp. の歩脚破片を産する事実 も, この考えと一致する。Macrocheira yabei (IMAIZuMI), 1957 とすべきであろう。歩 
脚破片 Macrocheira sp. と Macrocheira yabei との関係ば, 今後, 中間の大きさの試 料の蒐集をまって解決される問題であろう。 Macrocheira yabei の模式標本は現在, 横 浜大学に保存されているが, 午の登録番号, IGPS coll, cat. no. 79485 が, そのまま步 脚化石 Macrocheira sp. の番号として用いられた。

ここに，タカアシガニの祖先が，日本の中新世に生存していたことを報告する。 


\title{
Miocene Macrocheira from Japan*
}

\author{
Rikizo IMAIzUmi \\ Institute of Earth Science \\ College of Arts and Scienes, Tohoku University, Sendai
}

Introduction : One finger of a cheliped was collected on May, 1961 from the Kaminohata Sandstone member of the Ginzan Formation ${ }^{1}$ (SAITo, 1960) of Miocene age, exposed along the stream of Okamami-sawa, a tributary of Yakushi-sawa, Ginzan Hotsprings, Obanazawa City, Yamagata prefecture ${ }^{2)}$ by Assist. Prof. Tamio Kotaka and Dr. Tsunemasa SaIto of the Institute of Geology and Paleontology, Tohoku University.

The specimen consists of only the immovable finger, so it is difficult to determine its generic position. However, fortunately the finger (IGPS coll. cat, no. 90010) has a longitudinal broad furrow on the upper surface and preserves eight characteristic teeth. These features are similar to those of the immovable finger of the left cheliped of Macrocheira kaempferi DE HAAN, 183 .

Macrocheira kaempferi DE HAAN, 1839 is a Japaniese giant crab. The largest male spcimen hitherto known measures $330 \mathrm{~cm}$ (SAKAI) in width of extended legs. The measurements of a mele specimen reported by SAKAI (1938, p. 230) from Sagami Bay are : length of carapace, $335 \mathrm{~mm}$; width, $305 \mathrm{~mm}$; length of pseudorostrum, $38 \mathrm{~mm}$; length of cheliped, $1500 \mathrm{~mm}$.

The above cited species inhabits sandy or muddy bottoms, 50 to 300 metres deep and is endemic to Japan. It is distributed from off Kamaishi, Iwate Prefecture southwards to Kyushu.

The writer received a large leg of a crab collected from the middle part of the Miocene Yonekawa Formation, Tomikusa Group ${ }^{3)}$ exposed at the north cliff of the Chiyo Primary School Grounds, Yonekawa, Chiyo-mura, Shimoinagun, Nagano Prefecture ${ }^{4)}$ and one of Paratymolus yabei IMAizumi, 1957 from the

1）銀山層 上ノ烟砂岩部層

2）山形県尾花沢市銀川温泉薬師沢支流・オカマミ沢中部

3）富草層群米川層

4）長野県下伊那郡米川

* Read at the 63th Meeting of the Paleontological Society of Japan held at Sapporo, June 20,1956, at the 78th Meeting of the Paleontological Society of Japan hold at Akita, May 13, 1961 and at the General Meeting of the Geological Society of Northeast Japan held at Yamagata, October 10, 1964. 
Chiyo Middle School, when he visited the place in 1956. As stated in this paper the generic position of Paratymolus yabei should be changed to Macrochei$r a$ as Macrocheira yabei (Imaizumi), 1957.

The leg from Chiyo-mura, Nagano Prefecture has the propodus and dactylus covered thickly with wartlike tubercles. The surface ornamentations and the size of the leg well correspond to the ones of Macrocheira kaempferi, there fore it is described as Macrocheira sp. in this paper; the impression of the hepatic region of the carapace is also preserved.

The fossil finger from Ginzan, Yamagata Prefecture is named Macrocheira ginzanensis n. sp.

Acknowledgements : The writer expresses his deep thanks to Dr. Hisakatsu YABE Emeritus Professor and Prof. Kotora HataI of the Tohoku University for their guidances and to Dr. R. V. Kesling of the Museum of Paleontology, University of Michigan for his kind advices.

Thanks are also due to Assist. Prof. Tamio Kotaka and Dr. Tsunemasa SAITo of the Institute of Geology and Paleontology, Tohoku University, and to the Chiyo Middle School of Yonekawa-mura, Nagano Prefecture for their specimens.

Tribe BRACHYURA BORRADILE

Subtribe BRACHYGNATHA BORRADILE

Superfamily OXYRHYNCHA LATREILLE

Family MAJIDAE ALCOCK

Subfamily INACHINAE Alcock

Genus Macrocheira DE HAAN

DE HAAN 1839, p. 89 ; SAKAI 1938, p. 229.

Genotype : Macrocheira kaempferi DE HAAN, 1839

Macrocheira ginzanensis Imaizumi. n. sp.

Pl. IV, figs. $1 \sim 5$

A large immovgble finer of a left cheliped, $28 \mathrm{~mm}$ in length, $5 \sim 8 \mathrm{~mm}$ in width and $12 \mathrm{~mm}$ in maximum height.

It resembles the immovable finger of the left cheliped of Macrocheira kaempferi DE HAAN, 1839. 
The furrow on the upper surface of the fossil finger is broadly concave, and slightly and gradually curved inward where the width of the furrow is $4 \mathrm{~mm}$ in maximum, although the distal end of the furrow is enclosed by a roundish ridge. The tip of the finger is blent and globular.

The ridges on both sides of the furrow become thicker backwards from the distal end. The ridge on the outer side is narrower and shorter than the one on the inner side.

Eight teeth succeed the ridge on the outer side. The first tooth is oblong, and the second one is short and contiguous to the third one with an indistinct fosse. The third tooth is twice as long as the second one and shorter than the first one.

The fourth tooth is half as long as the fifth one which has rectangular upper view. The sixth tooth has a round upper view and is bluntly pointed forward. The seventh one is the most robust. The eighth one in also robust and slightly broader than the length. The fosse between the seventh and the eighth teeth is the broadest. The proximal edge behind the eighth tooth shows a round mark left by the broken ninth tooth and suggests that the broken ninth tooth had the same round shape as that of Macrocheira kaempferi.

There can be seen faint sculpture of five ridges running radiately at the distal part of the bottom of the furrow and one long and low ridge extending diagonally from the base of the second tooth to the inner angle near the tip.

A distinct groove runs along the upper border of the inner surface. In front of the groove, there are three sockets arranged at the same intervals from the tip.

Hexagonal patterns can be seen on some parts of the inner and lower surfaces.

Locality and geological horizon: At Middle stream of the Okamami-sawa, a tributary of Yakushi-sawa, Ginzan Hotsprings, Obanazawa City, Yamagata Prefecture. IGPS 1oc. no. Yt-5. Lat. $38^{\circ} 33^{\prime} 18^{\prime \prime}$. 4N., long. $140^{\circ} 33^{\prime} 35^{\prime \prime}$. 8E. Kaminohata Sandstone member, Ginzan Formation, Miocene.

Repository : IGPS coll. cat. no. 90010.

Remarks : The furrow on the upper surface, the shapes of the teeth and the groove and sockets on the inner surface of the fossil finger are quite identical with the immovable finger of the left cheliped of Macrocheira kaempferi. But by general proportions the fossil finger is distinguished from the 
Recent species. That is, the fossil finger is relatively broad, robust and thick compared with the left cheliped of a female specimen of Macrocheira kaempferi. This feature may depend upon sexual dimorphism or its specific character. Chelipeds of a male specimen of Macrocheira kaempferi are relatively longer than those of the female. But, the figures of the chelipeds shown in "Fauna japonica" have no such distinct sexual dimorphisms. So, the Miocene species of Macrocheira seems to have been relatively more robust and smaller than the Recent species.

That is to say that species of the Macrocheira became specialized to grow into giant size after the Miocene. Macrocheira kaempferi is endemic to Japan.

\section{Macrocheira sp.}

Pl. IV, figs. $10,11,14 \sim 16$

The impression of a leg with two fragmental segments embeded in the gray fine siltstone. The large segment, probably the distal part of the propodus, $17 \mathrm{~mm}$ in width; more than $80 \mathrm{~mm}$ in length, and the proximal part of dactylus. The surface is thickly covered with wartlike tubercles. Each tubercle has a central round depression. The tubercles are arranged in several obscurely defined longitudinal rows.

The impression of a fragment of a carapace is preserved apart from the leg of Macrocheira sp. on the same slab of siltstone. The impression just stated is the hepatic region with a spine of which the tip is broken off.

The hepatic region belongs to the left side of the carapace. There are seven wartlike tubercles and four or more small tubercles on the hepatic region. Two large tubercles among them are arranged on the postero-outer part of the region, two at the base of the spine and three large ones in the middle. Three to nine small round pits can be seen on the tubercles. Each pit has a round ring-like ornamentation (fig. 16). The arrangements of the tubercles on the hepatic region of the impression well correspond with the ones of Macrocheira kaempferi. The size of the impression is $4 \mathrm{~mm} \times 9 \mathrm{~mm}$ and suggests that the hepatic region belonged to a specimen different from the one of the large leg here described.

Locality and geological horizon: North cliff of the Chiyo Primary School Ground, Yonekawa, Chiyo-mura, Shimoina-gun, Nagano Prefecture, IGPS 1oc. no. N-5, lat. $35^{\circ} 25^{\prime} 2^{\prime \prime}$ N., long. $137^{\circ} 51^{\prime} 58^{\prime \prime}$. $6 \mathrm{E}$., middle part of Yonekawa Formation, Tomikusa Group, Miocene. 
Repository : IGPS coll. cat. no. 79485.

Remarks : Merely by the fragment of a leg, it is difficult to determine the species, therefore specific designation is withheld.

As already stated, the leg of the fossil Macrocheira was recovered with $\mathrm{Pa}$ ratymolus yabei IMAIZumi, 1957 from the middle part of the Yonekawa Formation, Tomikusa Group exposed at the north cliff of the Chiyo Primary School Ground, Yonekawa, Chiyo-mura, Nagano Prefecture.

Paratymolus yabei is very near to Paratymolus pubescene Miers, 1879. The eyestalks of Paratymolus yabei are longer and more stout than those of Paratymolus pubescens aud the rostrum of the former species is larger than the latter (IMAIzumi, 1957, p. 29). These features of Paratymolus yabei were once considered to be the ancestral characters of Paratymolus pubescens (Imaizumi, 1957). But, because the large leg of Macrocheira sp. has been found from the same place. the former opinion becomes invalid.

Both Paratymolus and Macrocheira are included in the Subfamily Inachinae Alcock. They are distingnished by the basal segments of the antennae and segmentations of the abdomens. It is difficult to find such characters in the small specimens of fossil crabs. The fossil crabs named as "Paratymolus yabei" by the writer, have the large exposed eyestalks and relatively large rostrums. The regions of the carapaces of "Paratymolus yabei" are indistinct but hepatic, proto-gastric, meso-gastric, epi-branchial, meso-branchial and postero-branchial regions are observed as already described by the writer. And the surfaces of the carapaces of "Paratymolus yabei" are ornamented densely with wartlike tubercles and wrinkles. The regions of the carapace of Paratymolus pubescens are "qute indistinct" as described by SAKAI (1938, p. 208). It must be borne in mind that the fossil small crabs named "Paratymolus yabei" by the writer are the young form of Macrocheira. So, the generic position of Paratymolus yabei Imaizumi, 1957 should be changed to Macrocheira and be called as Macrocheira yabei (IмAIzumi), 1957.

The type specimens of Paratymolus yabei formerly reposited in the Institute of Geology and Paleontology, Tohoku University (IGPS coll. cat. no. 79485) is now occupied by Macrocheira sp. described in this article.

The relations between Macrocheira yabei and the large leg of Macrocheira sp. are reserved for future study. It is revealed now that the ancestor of the giant crab, Macrocheira kaempferi existed in Japan during the Miocene age. 


\section{References}

ARAKAWA, Y. K., 1963 On Mating Behavior of Giant Japanese Crab, Macro. cheira kaempferi DE HAAN, Res. Crust., no. 1, p. 41 46, Pls. I IV

GreEN, J., 1961 A Biology of Crustacea, p. 1 180, 58 figs., Witherby.

IMAIzUmi, R., 1957 A Miocene Fossil Crab, Paratymolus Yabei n. sp. from Nagano Prefecture, Trans. Proc. Pal. Soc. Japan, N. S., no. 25, p. 26 $\sim 30$, Pl. 5, 1 text-fig.

1963 Historical Review of the Fossil Decapoda of Japan, Res. Crust., no. 1, p. 32 40, 2 figs.

GARTH, J. S., 1939 New Brachyuran Crabs from the Galapagos Islands, Allan Hancock Pacific Exp., v. 5, num. 2, p. 1 49, 10 Pls.

1940 Some New Species of Brachyuran Crabs from Mexico and the Central and South American Mainland, Allan Hancock Pacific Exp., v. 5, num. 3, p. 53 127, Pls. 11 26.

Glaessner, M. F., 1960 The Fossil Decapod Crustacea of New Zealand and the Evolution of the Order Decapoda, New Zealand Geol. Surv., Pal. Bull. 31, p. 1 63, Pls. 6 .

MEnzies, R. J., 1951 Pleistocene Brachyura from the Los Angeles Area, Cancridae, Jour. Pal, v. 25, no. 2, p. 165 170, 13 figs.

PANning, A., 1939 The Chinese Mitten Crab, Ann. Rep. Smith. Inst., p. 361 375, Pls. 1 9.

Rathbun, M. J., 1925 The Spider Crabs of America, U. S. Nat. Mus. Bull. 129, p. 1 613, 238 figs.

SAITO, T., $\quad 1960$ Tertiary Statiertigraphy of the Ou Backbone Range Bordering Yamagata and Miyagi Prefectures, Part I, The Western Border, Jour. Geol. Soc. Japan, v. 66 , no. 774 , p. $157 \sim 169$, figs. 4 , tabs. 3.

SAKAI, T., 1938 Studies on the Crabs of Japan, III. Brachygnatha, Oxyrhyncha, Sci. Rep. Tokyo Bunrika Daigaku, Sect. B, p. 193 364, 22 Pls., 55 text-figs., 1 tab..

SCHÄFER, W., 1954 Form und Funktion der Brachyuren-Schere, Abhandl. Senckenberg. Naturforsch. Gesellsch. 489, 128 Abb., s. 1 65.

\section{Explanation of Plate IV}

Figs. 1 5. Macrocheira ginzanensis IMAIZUMI, n. sp., x 1. 6 .

1-Upper view. 2-Inner view. 3-Outer view. 4-Lower view. 5-Front view.

IGPS coll. cat. no. 900010; IGPS loc. no. Yt-5. Kaminohata Sandostone member, Ginzan Formation, Miocene. Coll. T. KoTAKA and T. SAITo. 
Figs. 6 9. Immovable finger of the left cheliped of Macrocheira kaempferi DE HAAN, 1839, female, collected from Ise Bay; length of carapace, $210 \mathrm{~mm}$; width. $190 \mathrm{~mm}$; ; length of pseudorostrum, $33 \mathrm{~mm}$; length of cheliped, $300 \mathrm{~mm}, \mathrm{x} 1.6$. 6-Upper view. 7-Inter view. 8-Outer view. 9-Lower view.

Figs. 10, 11. Macrocheira sp.

10-Propodus dactylus, $\times 1$. 6. 11-Enlarged surface showing tubercles, $\times 8$. IGPS coll. cat. no. 79485; IGPS loc. no. N-5. Middle part of Yonekawa Formation, Tomikusa group, Miocene.

Figs. 12, 13. Macrocheira kaempferi DE HAAN, 1839, the same specimen as in figs. 6 9. 12-Enlarged inter surface of palm of the lelt cheliped.

13-Enlarged outer surface of propodus of the left first leg.

Figs. 14 16. Macrocheira sp.

14-Impression of hepatic region preserved on the same slab of the leg illustrated in fig. $10, \times 1.4$.

15-Impression of left hepartic region, $\mathrm{x} 6$.

16-Enlarged pits with ring-like ornamentations on the tubercles, $x 25$.

Figs. 17. Macrocheira yabei (IMAIZUMI), 1957.

Well preserved specimen in dorsal view with impression of abdomen, $x$ 3. IGPS loc. no. N-5, middle part of Yonekawa Formation, Tomikusa Group, Miocene. 
36 Researches on Crustacea. No. 2

Pl. IV
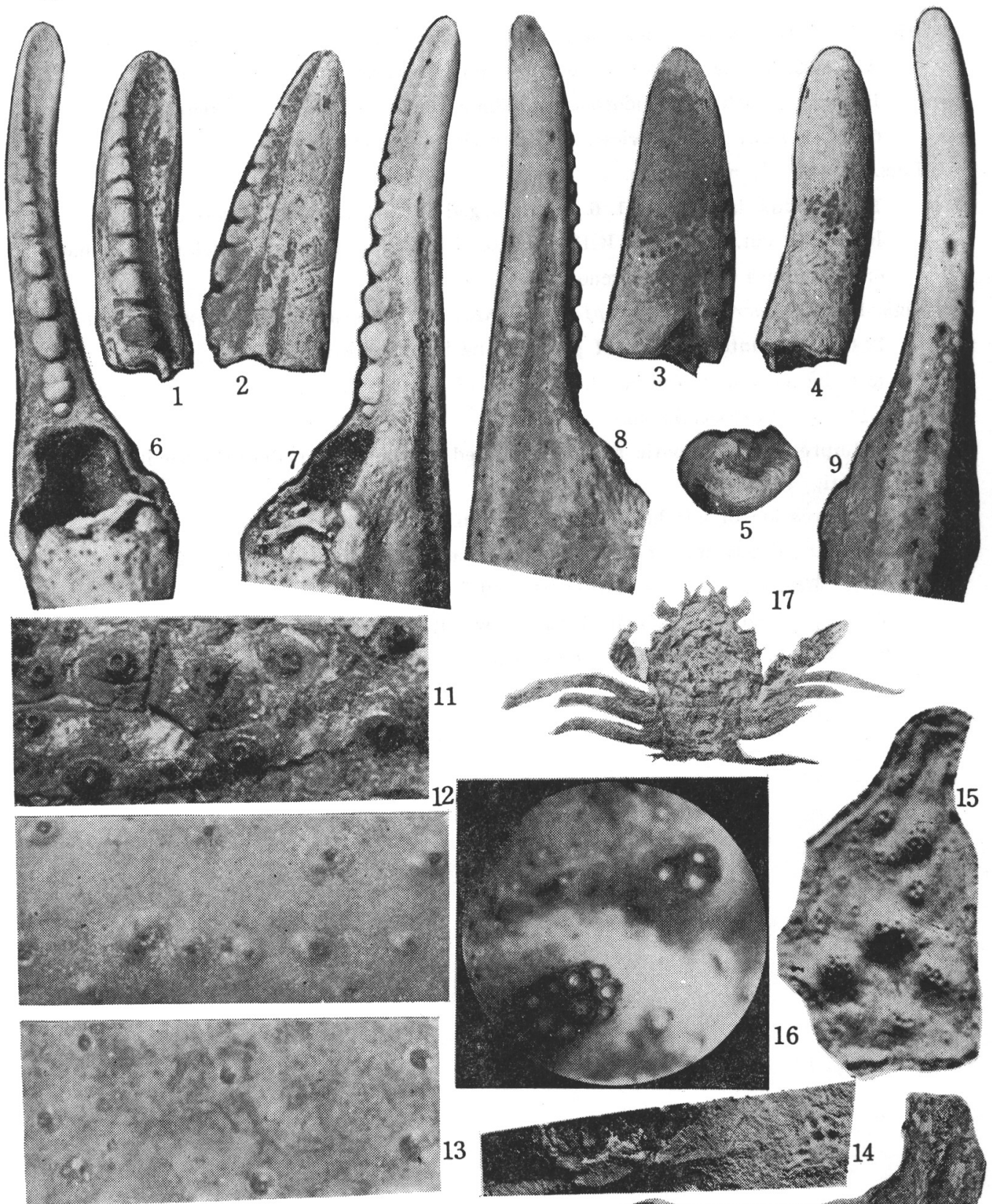

13
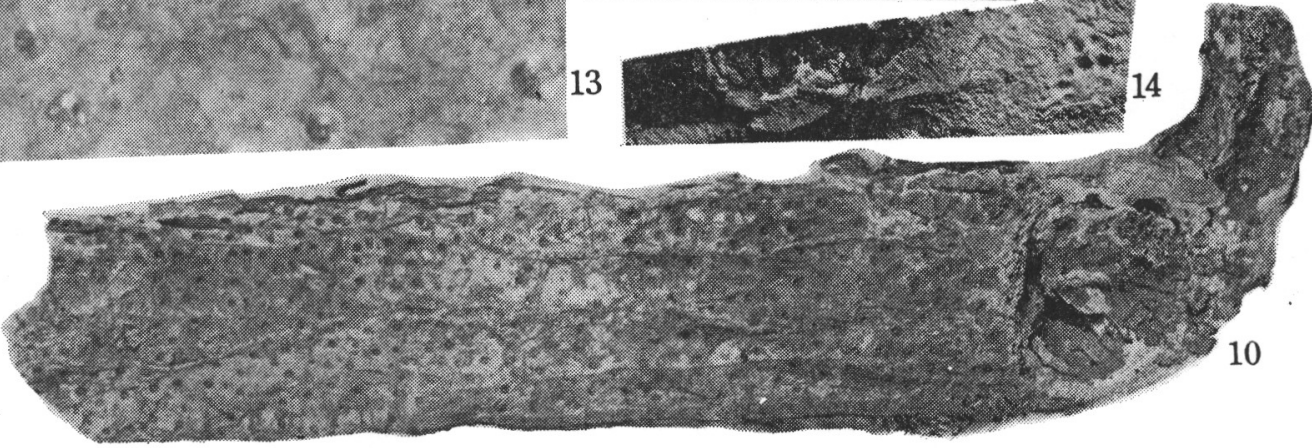

R. IMAIZUMI ; Mocene Macrocheira from Japan 